\title{
Profil Pasien Hemodialisis Inisiasi Di RSUD Arifin Achmad Provinsi Riau Periode Januari - Desember 2017
}

\author{
Elsa Tubella, ${ }^{1 *}$ Ligat Pribadi Sembiring, ${ }^{2}$ Fridayenti $^{3}$
}

\begin{abstract}
Hemodialysis is defined as the process of separation, filtering, or cleansing of blood through a semipermeable membrane in patients renal failure. Indication of hemodialysis for both diseases is clinical conditions in addition to laboratory results, such as signs of fluid overload, electrolyte imbalance, metabolic acidosis, and signs of anemia. This study purposed to describe the profile of patients initiation hemodialysis in RSUD Arifin Achmad Riau Province Period January-December 2017. This research was a retrospective descriptive. This study used 94 samples. The number of male patients were higher than female patients (60.6\%). The most age group was 40-59 years (57.4\%). Second degree of hypertension was $46,8 \%$. The study showed $92.55 \%$ of patients had anemia, $50 \%$ had hyperkalemia, $56.4 \%$ had hyponatremia, and $41.5 \%$ had acidosis. Patients consisted of $81.9 \%$ chronic kidney disease, and $18.1 \%$ acute renal failure.
\end{abstract}

Keywords: Hemodialysis, Chronic kidney disease, Acute kidney injury

Hemodialisis diartikan sebagai proses pemisahan, penyaringan, atau pembersihan darah melalui suatu membran semipermeabel pada pasien gangguan fungsi ginjal akut maupun kronik. ${ }^{1}$ Hemodialisis menjadi salah satu terapi gagal ginjal kronik selain dialisis peritoneal yang digunakan untuk mempertahankan penderita dalam keadaan klinis yang optimal sampai tersedia donor ginjal. Prinsip terapi hemodialisis adalah difusi zat terlarut dan air dari plasma ke larutan dialisis sebagai respon terhadap perbedaan konsentrasi dan tekanan. ${ }^{2}$

Menurut data USRDS 2017, insiden end stage renal disease (ESRD) pada tahun 2014 di Amerika Serikat adalah sebanyak 120.688 kasus. Sebanyak $87,9 \%$ kasus memulai terapi penggantian ginjal dengan hemodialisis, 9,3\% memulai dengan peritoneal dialisis dan $2,6 \%$ menerima transplantasi ginjal preemptif. ${ }^{3}$

Menurut data dari $8^{\text {th }}$ report of Indonesian Renal Registry tahun 2015 oleh PERNEFRI

\footnotetext{
* Email Korespondensi : elsatubella@yahoo.com

1 Fakultas Kedokteran Universitas Riau

2 KJFD Ilmu Penyakit Dalam Fakultas Kedokteran Universitas Riau

3 KJFD Patologi Klinik Fakultas Kedokteran Universitas Riau
}

(Perkumpulan Nefrologi Indonesia) di Indonesia, terdapat 21.050 pasien baru hemodialisis dan 30.554 pasien aktif. Pasien baru adalah pasien yang menjalani terapi hemodialisis untuk pertama kali (hemodialisis inisiasi) pada tahun 2015. Pasien aktif adalah pasien baru maupun pasien lama yang telah menjalani terapi hemodialisis dari tahun sebelumnya dan masih menjalani terapi hemodialisis rutin dan masih hidup pada 31 Desember 2015. Menurut data ini, jumlah pasien baru terus meningkat setiap tahunnya. Jumlah pasien ini belum menunjukkan data seluruh Indonesia, tetapi dapat dijadikan representasi dari kondisi saat ini ${ }^{4}$

Indikasi terapi penggantian ginjal (TPG) pada pasien gangguan ginjal akut (GgGA) sangat luas, tergantung kondisi klinik yang dihadapi. Saat ini, kriteria yang biasa dipakai menjadi dasar untuk dialisis inisiasi pada gangguan ginjal akut adalah gejala klinik kelebihan cairan dan penanda biokimia tentang terjadinya ketidakseimbangan elektrolit, seperti hiperkalemia, azotemia, atau asidosis metabolik. $^{5}$

Menurut panduan dari Kidney Disease Outcome Quality Initiative (KDOQI), terapi penggantian ginjal dilakukan pada pasien penyakit 
ginjal kronik stadium 5, yaitu dengan kriteria glomerulus filtration rate (GFR) kurang dari 15 $\mathrm{ml} / \mathrm{menit} / 1,73 \mathrm{~m}^{2}$, ditambah beberapa keadaan berikut, yaitu : kelebihan cairan ekstrasel yang sulit dikendalikan dan/ hipertensi; hiperkalemia yang refrakter terhadap restriksi diet dan terapi farmakologis; asidosis metabolik yang refrakter terhadap pemberian terapi bikarbonat; hiperfosfatemia yang refrakter terhadap restriksi diet dan terapi pengikat fosfat; anemia yang refrakter terhadap pemberian eritropoietin dan besi; adanya penurunan kapasitas fungsional atau kualitas hidup tanpa penyebab yang jelas; penurunan berat badan atau malnutrisi; adanya gangguan neurologis, pleuritis, atau perikarditis yang tidak disebabkan oleh penyebab lain, serta diathesis hemoragik dengan pemanjangan waktu perdarahan. ${ }^{1}$ Panduan ini menjadi dasar penentuan hemodialisis di RSUD Arifin Achmad Provinsi Riau.

Berdasarkan latar belakang tersebut maka penulis ingin mengetahui "bagaimana profil pasien hemodialisis inisiasi di RSUD Arifin Achmad Provinsi Riau Periode Januari - Desember 2017?"

\section{METODE}

Penelitian ini merupakan penelitian yang bersifat deskriptif retrospektif dengan menggunakan data rekam medis pasien hemodialisis inisiasi di RSUD Arifin Achmad Provinsi Riau periode Januari
- Desember 2017. Penelitian ini dilaksanakan di Instalasi Rekam Medis RSUD Arifin Achmad Provinsi Riau pada bulan April - Juni 2017. Populasi dalam penelitian ini adalah seluruh data rekam medis pasien hemodialisis inisiasi di Instalasi Rekam Medis RSUD Arifin Achmad Provinsi Riau periode Januari - Desember 2017.

Sampel dalam penelitian ini adalah seluruh pasien hemodialisis inisiasi yang memenuhi kriteria inklusi pada bulan Januari - Desember 2017 di RSUD Arifin Achmad Provinsi Riau. Teknik pengambilan sampel dilakukan dengan metode total sampling, yaitu teknik pengambilan sampel dengan cara mengambil seluruh anggota populasi sebagai responden atau sampel.

\section{Kriteria Inklusi}

Seluruh data rekam medis pasien yang diputuskan untuk hemodialisis inisiasi di RSUD Arifin Achmad Provinsi Riau pada periode Januari Desember 2017 dan mempunyai data rekam medik yang lengkap.

\section{HASIL}

Distribusi frekuensi pasien hemodialisis inisiasi berdasarkan karakteristik dan tekanan darah dapat dilihat pada tabel 1 .

Tabel 1. Distribusi frekuensi pasien hemodialisis inisiasi berdasarkan karakteristik dan tekanan darah.

\begin{tabular}{|c|c|c|c|}
\hline Variabel & $\begin{array}{l}\text { Penyakit Ginjal } \\
\text { Kronik }(\%)\end{array}$ & $\begin{array}{l}\text { Gangguan Ginjal } \\
\text { Akut }(\%)\end{array}$ & Total $(\%)$ \\
\hline \multicolumn{4}{|l|}{ Usia } \\
\hline - $<20$ tahun & $1(1,3)$ & $0(0)$ & $1(1,1)$ \\
\hline - $20-39$ tahun & $13(16,9)$ & $5(29,4)$ & $18(19,1)$ \\
\hline - 40 - 59 tahun & $48(62,3)$ & $6(35,3)$ & $54(57,4)$ \\
\hline - $=60$ tahun & $15(19,5)$ & $6(35,3)$ & $21(22,3)$ \\
\hline \multicolumn{4}{|l|}{ Jenis Kelamin } \\
\hline - Laki-laki & $47(61)$ & $10(58,8)$ & $57(60,6)$ \\
\hline - Perempuan & $30(39)$ & $7(41,2)$ & $37(39,4)$ \\
\hline Tekanan darah & & & \\
\hline - $\operatorname{Normal}(<120 / 80$ mmHg) & $2(2,6)$ & $3(17,6)$ & $5(5,3)$ \\
\hline $\begin{array}{l}\text { - Pre-hipertensi (120 -139/80- } \\
89 \mathrm{mmHg})\end{array}$ & $18(23,4)$ & $4(23,5)$ & $22(23,4)$ \\
\hline $\begin{array}{l}\text { - Hipertensi derajat } 1(140 \\
159 / 90-99 \mathrm{mmHg})\end{array}$ & $14(18,2)$ & $9(53)$ & $23(24,5)$ \\
\hline $\begin{array}{l}\text { Hipertensi derajat } 2 \\
(=160 / 100)\end{array}$ & $43(55,8)$ & $1(5,9)$ & $44(46,8)$ \\
\hline
\end{tabular}


Berdasarkan hasil penelitian, didapatkan jumlah pasien terbanyak berdasarkan kelompok umur yaitu pada umur 40 - 59 tahun sebanyak 54 orang $(57,4 \%)$ dan yang paling sedikit pada kelompok umur $<20$ tahun sebanyak 1 orang $(1,1 \%)$. Pasien laki-laki lebih banyak daripada perempuan, yaitu sebanyak 57 orang $(60,6 \%)$ dan $37(39,4 \%)$.
Distribusi klasifikasi tekanan darah yang paling sering pada pasien hemodialisis inisiasi berturut-turut adalah hipertensi derajat 2 sebanyak 44 pasien $(46,8 \%)$, hipertensi derajat 123 pasien $(24,5 \%)$, prehipertensi 22 pasien $(23,4 \%)$, dan normotensi sebanyak 5 pasien $(5,3 \%)$.

Tabel 2. Distribusi frekuensi gejala klinik penurunan kesadaran, sesak napas, mual muntah, dan edema pada pasien hemodialisis inisiasi

\begin{tabular}{lcc}
\hline Variabel & Ya $(\%)$ & Tidak (\%) \\
\hline Penurunan kesadaran & $14(14,9 \%)$ & $80(85,1 \%)$ \\
Sesak napas & $64(68,1)$ & $30(31,9 \%)$ \\
Mual muntah & $44(46,8 \%)$ & $50(53,2 \%)$ \\
Edema & $45(47,9 \%)$ & $49(52,1 \%)$ \\
\hline
\end{tabular}

Berdasarkan hasil penelitian ini, didapatkan gejala klinik yang paling sering dialami pasien yang akan menjalani terapi hemodialisis inisiasi berturutturut adalah sesak napas 64 pasien $(68,1 \%)$, edema 45 pasien $(47,9 \%)$, mual muntah 44 pasien $(46,8 \%)$, dan penurunan kesadaran 14 pasien $(14,9 \%)$.
Distribusi frekuensi pemeriksaan laboratorium yaitu kadar hemoglobin, kadar kalium darah, kadar natrium darah, $\mathrm{pH}$ darah ureum darah dan estimated GFR (eGFR) dapat dilihat pada tabel 3.

Tabel 3. Distribusi frekuensi pemeriksaan laboratorium yaitu kadar hemoglobin, kadar kalium darah, kadar natrium darah, $\mathrm{pH}$ darah, ureum darah, dan eGFR.

\begin{tabular}{|c|c|c|c|}
\hline Variabel & $\begin{array}{c}\text { Penyakit Ginjal } \\
\text { Kronik }(\%)\end{array}$ & $\begin{array}{c}\text { Gangguan Ginjal } \\
\text { Akut }(\%)\end{array}$ & Total $(\%)$ \\
\hline \multicolumn{4}{|l|}{ Hb laki-laki } \\
\hline Anemia & $46(97,9)$ & $8(80)$ & $54(94,7)$ \\
\hline Tidak anemia & $1(2,1)$ & $2(20)$ & $3(5,3)$ \\
\hline \multicolumn{4}{|l|}{$\mathrm{Hb}$ perempuan } \\
\hline Anemia & $28(93,3)$ & $5(71,4)$ & $33(89,2)$ \\
\hline Tidak anemia & $2(6,7)$ & $2(28,6)$ & $4(10,8)$ \\
\hline \multicolumn{4}{|l|}{ Kalium darah } \\
\hline Hipokalemia & $9(11,7)$ & $3(17,6)$ & $12(12,8)$ \\
\hline Normal & $28(36,4)$ & $7(41,2)$ & $35(37,2)$ \\
\hline Hiperkalemia & $40(52)$ & $7(41,2)$ & $47(50)$ \\
\hline \multicolumn{4}{|l|}{ Natrium darah } \\
\hline Hiponatremia & $44(57,1)$ & $9(52,9)$ & $53(56,4)$ \\
\hline Normal & $23(29,9)$ & $6(35,3)$ & $29(30,8)$ \\
\hline Hipernatremia & $10(13)$ & $2(11,8)$ & $12(12,8)$ \\
\hline \multicolumn{4}{|l|}{$\mathrm{pH}$ darah } \\
\hline Asidosis & $37(48)$ & $2(11,8)$ & $39(41,5)$ \\
\hline Normal pH & $10(13)$ & $0(0)$ & $10(10,6)$ \\
\hline Alkalosis & $2(2,6)$ & $0(0)$ & $2(2,1)$ \\
\hline Tidak di periksa & $28(36,4)$ & $15(88,2)$ & $43(45,8)$ \\
\hline \multicolumn{4}{|l|}{ Ureum darah } \\
\hline$=100 \mathrm{mg} / \mathrm{dl}$ & $7(9,1)$ & $2(11,8)$ & $9(9,6)$ \\
\hline $101-200 \mathrm{mg} / \mathrm{dl}$ & $34(44,1)$ & $8(47)$ & $42(44,7)$ \\
\hline $201-300 \mathrm{mg} / \mathrm{dl}$ & $21(27,3)$ & $5(29,4)$ & $26(27,7)$ \\
\hline $301-400 \mathrm{mg} / \mathrm{dl}$ & $11(14,3)$ & $2(11,8)$ & $13(13,8)$ \\
\hline$>401 \mathrm{mg} / \mathrm{dl}$ & $4(5,2)$ & $0(0)$ & $4(4,2)$ \\
\hline eGFR & & & \\
\hline$<15 \mathrm{ml} /$ menit & $75(97,4)$ & $13(76,4)$ & $88(93,6)$ \\
\hline $15-30 \mathrm{ml} / \mathrm{menit}$ & $2(2,6)$ & $2(11,8)$ & $4(4,3)$ \\
\hline$>30 \mathrm{ml} / \mathrm{menit}$ & $0(0)$ & $2(11,8)$ & $2(2,1)$ \\
\hline
\end{tabular}


Berdasarkan hasil penelitian pada tabel 3, didapatkan sebanyak 87 pasien $(92,6 \%)$ yang menjalani hemodialisis inisiasi mengalami anemia. Berdasarkan kadar kalium darah, 12 pasien (12,8\%) dalam keadaan hipokalemia, 35 pasien $(37,2 \%)$ dalam keadaan normokalemia, dan 47 pasien (50\%) dalam keadaan hiperkalemia. Sementara itu, berdasarkan kadar natrium darah didapatkan 53 pasien $(56,4)$ dalam keadaan hiponatremia, 29 pasien $(30,9 \%)$ dalam keadaan kadar natrium normal, dan 12 pasien $(12,8 \%)$ dalam keadaan hipernatremia.

Pada penelitian ini juga ditemukan jumlah kejadian asidosis sebanyak 39 pasien $(41,5 \%)$, pasien dengan $\mathrm{pH}$ normal 10 pasien $(10,6 \%)$, kejadian alkalosis sebanyak 2 pasien $(2,1 \%)$ sementara pada 43 pasien $(45,7 \%)$ tidak dilakukan pemeriksaan analisa gas darah. Hasil pemeriksaan ureum ditemukan kelompok ureum 101 - 200 adalah yang terbanyak dengan jumlah 42 pasien $(44,7 \%)$.

Berdasarkan eGFR, 90 pasien $(95,7 \%)$ memiliki eGFR $<15 \mathrm{ml} /$ menit, 3 pasien $(3,2 \%)$ memiliki eGFR $15-30 \mathrm{ml} / \mathrm{menit}$, dan 1 pasien $(1,1 \%)$ memiliki eGFR $>30 \mathrm{ml} /$ menit.

Distribusi frekuensi diagnosis penyakit utama dan diagnosis etiologi pasien hemodialisis inisiasi dapat dilihat pada tabel 4.

Tabel 4. Distribusi frekuensi diagnosis penyakit utama dan diagnosis etiologi pasien hemodialisis inisiasi

\begin{tabular}{lcc}
\hline \multicolumn{1}{c}{ Diagnosis utama } & Frekuensi (n=94) & Persentase $(\%)$ \\
\hline Penyakit Ginjal Kronik (PGK) & 77 & $81,9 \%$ \\
Nefropati diabetic & 22 & 28,6 \\
Hipertensi & 39 & 50,6 \\
Glomerulopati primer (GNC) & 2 & 2,6 \\
Pielonefritis kronik & 1 & 1,3 \\
Uropati obstruksi & 11 & 14,3 \\
Nefropati lupus & 1 & 1,3 \\
Lain-lain & 1 & 1,3 \\
Gangguan Ginjal Akut (GgGA) & 17 & $18,1 \%$ \\
Pre-renal & 4 & 23,5 \\
Intrinsik & 5 & 29,4 \\
Post-renal & 8 & 47,1 \\
\hline
\end{tabular}

Berdasarkan hasil penelitian pada tabel 4 didapatkan jumlah pasien berdasarkan diagnosis utama adalah 77 pasien $(81,9 \%)$ menderita penyakit ginjal kronik dan 17 pasien $(18,1 \%)$ menderita gagal ginjal akut.

Berdasarkan hasil penelitian ini, didapatkan diagnosis etiologi pasien penyakit ginjal kronik yang menjalani terapi hemodialisis inisiasi terbanyak berturut-turut adalah hipertensi 39 pasien $(50,6 \%)$, nefropati diabetik 22 pasien $(28,6 \%)$, uropati obstruksi 11 pasien $(14,3 \%)$, dan pielonefritis kronis, nefropati lupus, dan lain-lain masing-masing 1 pasien $(1,3 \%)$.

Berdasarkan hasil penelitian ini, didapatkan diagnosis etiologi pasien penyakit ginjal kronik yang menjalani terapi hemodialisis inisiasi terbanyak berturut-turut adalah hipertensi 39 pasien $(50,6 \%)$, nefropati diabetik 22 pasien $(28,6 \%)$, uropati obstruksi 11 pasien (14,3\%), dan pielonefritis kronis, nefropati lupus, dan lain-lain masing-masing 1 pasien $(1,3 \%)$.

\section{PEMBAHASAN}

Berdasarkan hasil penelitian ini, didapatkan jumlah pasien terbanyak berdasarkan umur yaitu kelompok umur 40 - 59 tahun sebanyak 54 orang $(57,4 \%)$, dan yang paling sedikit pada kelompok umur $<20$ tahun sebanyak 1 orang $(1,1 \%)$. Banyaknya jumlah pasien hemodialisis inisiasi pada usia lanjut mungkin dikarenakan sebagian besar pasien merupakan pasien penyakit ginjal kronik, dengan diagnosis etiologi terbanyak adalah hipertensi. Menurut Harford (2016), dua faktor yang mempengaruhi peningkatan prevalensi penyakit ginjal kronik adalah usia tua dan peningkatan prevalensi diabetes melitus dan hipertensi, yang keduanya meningkat pada usia lanjut. ${ }^{6}$ Semakin tua usia seseorang, risiko hipertensi semakin tinggi. Hal ini disebabkan karena elastisitas pembuluh darah mengalami penurunan, menyebabkan penyempitan pembuluh darah, dan tekanan darah menjadi 
meningkat. ${ }^{7}$

Pasien laki-laki lebih banyak daripada pasien perempuan, yaitu sebanyak 57 orang $(60,6 \%)$ dan 37 orang $(39,4 \%)$. Berdasarkan kepustakaan, hal ini dapat disebabkan oleh pengaruh perbedaan hormon reproduksi, gaya hidup seperti konsumsi protein, garam, rokok dan konsumsi alkohol pada laki-laki dan perempuan. ${ }^{8}$

Rincian gejala klinik yang paling sering dialami pasien yang akan menjalani terapi hemodialisis inisiasi berturut-turut adalah sesak napas 64 pasien $(68,1 \%)$, edema 45 pasien $(47,9 \%)$, mual muntah 44 pasien $(46,8 \%)$, dan penurunan kesadaran 14 pasien $(14,9 \%)$.

Penurunan kesadaran adalah manifestasi ensefalopati uremikum pada penyakit ginjal kronik. ${ }^{9}$ Gagal ginjal menyebabkan akumulasi berbagai racun uremik. Terdapat 4 senyawa guanidin yang secara substansial meningkat dalam serum, cairan serebrospinal, dan otak pasien gagal ginjal. Senyawa tersebut adalah kreatinin, guanidin, guanidinosuccinic acid, dan methylguanidine. ${ }^{10}$ Berdasarkan penelitian ini, 56 pasien $(72,7 \%)$ pasien penyakit ginjal kronik mengalami sesak napas. Mual dan muntah merupakan manifestasi dari keadaan asidosis pada pasien penyakit ginjal kronik. Edema perifer merupakan salah satu manifestasi akibat retensi natrium dan air pada pasien gagal ginjal terminal. Edema adalah akumulasi cairan abnormal di ruang interstisial tubuh. ${ }^{2}$

Dari penelitian ini, sebanyak 87 pasien $(92,6 \%)$ yang menjalani hemodialisis inisiasi mengalami anemia dan 74 pasien $(96,1 \%$ ) penyakit ginjal kronik mengalami anemia. Anemia pada pasien penyakit ginjal kronik gangguan kompleks yang ditentukan oleh banyak faktor. Selain berkurangnya produksi eritropoietin oleh ginjal, beberapa faktor lain juga mempengaruhi, seperti defisiensi besi, B12, dan folat karena ketidakcukupan nutrisi atau peningkatan kehilangan darah, memperpendek kelangsungan hidup sel darah merah. Anemia biasanya muncul pada tingkat GFR dibawah $60 \mathrm{ml} /$ menit. $^{11}$

Berdasarkan hasil penelitian ini, pada pasien penyakit ginjal kronik didapatkan 9 pasien $(11,7 \%)$ hipokalemia, 28 pasien (36,4\%) normokalemia, dan 40 pasien $(52 \%)$ hiperkalemia. Normalnya, ion kalium tersaring bebas melalui membran glomerulus.
Reabsorbsi kalium sebanyak 90 - 95\% secara konstan dan tanpa dikendalikan di tubulus proksimal dan lengkung henle. Sekresi $\mathrm{K}^{+}$terjadi di tubulus distal bervariasi dan di bawah kontrol. Hilangnya fungsi nefron karena gagal ginjal menghasilkan retensi kalium di renal. Keadaan ini dikompensasi dengan peningkatan sekresi kalium oleh nefron yang tersisa. Peningkatan kalium menyertai perburukan fungsi ginjal. Semakin menurun GFR, mekanisme kompensasi gagal menjaga keseimbangan kalium, sehingga keadaan hiperkalemia menjadi menetap. ${ }^{12}$

Pada pasien penyakit ginjal kronik, ditemukan 44 pasien $(57,1 \%)$ hiponatremia, 23 pasien $(29,8 \%)$ normonatremia, dan $10(13 \%)$ pasien hipernatremia. Gangguan pada konsentrasi natrium serum disebabkan oleh ketidakseimbangan air yang menyebabkan perubahan konsentrasi $\mathrm{Na}^{+}$terhadap air. Asupan cairan dan sirkulasi AVP (Arginine Vasopressin) adalah dua kunci penting yang mempertahankan osmolalitas darah. Defek pada salah satunya menjadi penyebab banyak kasus hipernatremia ataupun hiponatremia. Hiponatremia hipervolemia dapat terjadi karena aktivasi neurohumoral menyebabkan peningkatan produksi AVP, yang selanjutnya menyebabkan retensi air dan natrium. Peningkatan total $\mathrm{Na}^{+}$dan $\mathrm{Cl}^{-}$yang bersamaan dengan peningkatan air yang lebih besar menyebabkan keadaan hiponatremia. ${ }^{13}$

Pada penelitian ini juga ditemukan jumlah kejadian asidosis sebanyak 39 pasien $(41,5 \%)$, pasien dengan $\mathrm{pH}$ normal 10 pasien $(10,6 \%)$, kejadian alkalosis sebanyak 2 pasien $(2,1 \%)$ dan sebanyak 43 pasien $(45,7 \%)$ tidak dilakukan pemeriksaan $\mathrm{pH}$ darah. Pemeriksaan $\mathrm{pH}$ darah tidak dilakukan pada sebagian besar pasien mungkin dikarenakan tidak ditemukannya gejala sesak napas pada pasien.

Pada gagal ginjal, gangguan kemampuan ginjal untuk mengekskresikan $\mathrm{H}^{+}$mengakibatkan asidosis sistemik disertai penurunan kadar bikarbonat $\left(\mathrm{HCO}_{3}\right)$ dan $\mathrm{pH}$ plasma. Kadar $\mathrm{HCO}_{3}{ }^{-}$menurun karena digunakan untuk mendapatkan $\mathrm{H}^{+}$. Ekskresi ion amonium $\left(\mathrm{NH}_{4}^{+}\right)$merupakan mekanisme utama ginjal dalam usahanya mengeluarkan $\mathrm{H}^{+}$dan pembentukan kembali $\mathrm{HCO}_{3}^{-}$. Pada gagal ginjal, ekskresi $\mathrm{NH}_{4}^{+}$total berkurang karena berkurangnya jumlah nefron. Ekskresi fosfat merupakan mekanisme lain untuk mengekskresikan $\mathrm{H}^{+}$dalam bentuk asam yang dapat dititrasi. Namun, kecepatan 
ekskresi fosfat ditentukan oleh kebutuhan untuk mempertahankan keseimbangan fosfat, bukan untuk mempertahankan keseimbangan asam basa. Pada gagal ginjal, fosfat cenderung tertahan dalam tubuh karena berkurangnya massa nefron dan karena faktor-faktor yang berkaitan dengan metabolism kalsium yang akan dijelaskan kemudian. Retensi sulfat dan anion organik lainnya juga berperan dalam penurunan jumlah $\mathrm{HCO}_{3}-{ }^{2}$

\section{SIMPULAN}

Karakteristik terbanyak pasien hemodialisis inisiasi di RSUD Arifin Achmad periode Januari Desember 2017 adalah kelompok umur 40 - 59 tahun dengan persentase laki-laki lebih banyak. Klasifikasi tekanan darah pada pasien hemodialisis terbanyak adalah hipertensi derajat 2 . Gejala klinis yang paling banyak dirasakan adalah sesak napas. Berdasarkan hasil laboratorium sebagian besar pasien mengalami anemia, hiperkalemia, hiponatremia dan asidosis. Berdasarkan diagnosis penyakit utama, sebagian besar pasien mengalami penyakit ginjal kronik. Diagnosis etiologi terbanyak terjadinya penyakit ginjal kronik adalah hipertensi. Distribusi diagnosis etiologi gangguan ginjal akut yang terbanyak adalah postrenal.

\section{DAFTAR PUSTAKA}

1. Suhardjono. Hemodialisis; Prinsip dasar dan pemakaian kliniknya. In: Setiati S, Alwi I, Sudoyo A, Simadibrata M, Setiyohadi B, Fahrial A, editors. Buku Ajar Ilmu Penyakit Dalam Edisi VI. Jakarta: Interna Publishing; 2014. p. 219296.

2. Price SA, Wilson LM. Patofisiologi konsep klinis proses-proses penyakit 6(2). Jakarta: EGC; 2005.

3. United States Renal Data System. USRDS : Annual data reports. USRDS [internet]. 2017 [cited 2017 Jun 10]. Available from : https:// www.usrds.org.
4. Pernefri. $8^{\text {th }}$ report of Indonesian Renal Registry 2015. Pernefri [internet]. 2015 [diakses 10 Juni 2017]. available from : www. indonesianrenalregistry.org.

5. Roesli, Rully MA. Diagnosis dan pengelolaan gangguan ginjal akut. Edisi II. Jakarta: Puspa Swara; 2011.

6. Harford R, Clark MJ, Norris KC, Yan G. Relationship between age and pre-end stage renal disease care in elderly patients treated with hemodialysis. Nephrol Nurs J. 2016; 43(2):101108.

7. Tilong AD. Waspada penyakit-penyakit mematikan tanpa gejala menyolok. Jogjakarta: Buku Biru; 2014.

8. Sulistiowati E, Idailani S. Faktor risiko penyakit ginjal kronik berdasarkan Analisis cross-sectional data awal studi kohort penyakit tidak menular penduduk usia 25 - 65 tahun di Kelurahan Kebon Kelapa, Bogor. Buletin Penelitian Kesehatan. 2015; 43(3) p. 163-72.

9. Bucurescu G. Neurological manifestations of uremic encephalopathy. 2016 [cited 30 November 2017]. Available from https:// emedicine.medscape.com/article/1135651overview

10. Scaini G, Ferreira GK, Streck EL. Mechanism underlying uremic encephalopathy. Rev Bras Ter Intensiva. 2010; 22(2):206-211.

11. Afshar R, Sanavi S, Salimi J, Ahmadzadeh M. Hematological profile of chronic kidney disease (CKD) patients in Iran, in pre-dialysis stages and after initiation of hemodialysis. Saudi J Kidney Dis Transpl. 2010;21(2):368-371.

12. National Kidney Foundation. Clinical update on hyperkalemia. 2014.

13. Mount DB. Fluids and Electrolites disturbances. In: Longo DL, Kasper DL, Jameson JL, Fauci AS, Hauser SL, Loscalzo J, editors. Harrison's principles of internal medicine $18^{\text {th }} \mathrm{Ed}$. New York: Mc Graw Hill Medical; 2012. p. 341-359. 